\title{
Sõnatähenduste normimisest eesti keelekorralduses verbi vabandama näitel
}

\author{
LYDIA RAADIK
}

1980. aastal leidis vabariiklik õigekeelsuskomisjon (VÕK), et eesti keele sagedasti esinevate üldkeelesõnade tähendusi ja kasutust ei ole vajalik ega võimalik ette kirjutada, sest leksikaalne tähendus on kõige kiiremini muutuv element keeles ja selle nihkeid ei ole suuteline fikseerima ka kõige operatiivsem õigekeelsusorgan (Viks 1985: 72). Sellegipoolest on alates „Eesti keele sõnaraamatust ÕS 1999” osa sõnade tähendusi ebasoovitatavaks märgitud. Esialgu rangemalt sõnastuses „ei tähenda”, seejärel alates ÕS 2006-st leebemalt sõnastuses „ei soovita tähendus(t)es”, sest eesti keelekorralduses on tegelikult alates 1980. aastatest mindud soovituslikumat teed (Erelt 2002: 256). Täpsemalt on ÕS 1999-s 160, ${ }^{1}$ ÕS 2006-s 178, ÕS 2013-s 107 ja ÕS 2018-s 130 mõne ebasoovitatava tähendusega sõna. ${ }^{2}$ Nende hulgas on näiteks sellised üldkasutatavad sõnad nagu erinev, kaasaegne, kostuma, reisija, vabandama, ühistransport. Emakeele Seltsi keeletoimkond on jätkanud VÕK-i vaimus ja hoidunud sõnatähenduste valdkonnas iga detaili ettekirjutamisest ning on oma otsustega tähenduspiire pigem laiendanud, kui kitsendanud. Kuna keeletoimkond on siiani käsitlenud ainult üksikute sõnade tähendusi (Raadik, M. 2019: 67) ${ }^{3}$ ega ole vaadanud sõnatähenduste normimist ÕS-is üldiselt ja toimkond ei osale otseselt ÕS-i koostamises ${ }^{4}$, püsib olukord, kus osal sõnadest on ÕS-is mõni tähendus märgitud ebasoovitatavaks. Kas tähenduste ettekirjutus üldkeeles on tänapäeval asjakohane? Mida ja kas üldse peaks õigekeelsussõnaraamat sõnatähenduste kohta ette kirjutama?

XX sajandi esimesel poolel ja keskpaiku ühiskirjakeelt alles kujundati, sest inimeste emakeel oli valdavalt kohalik murre - nii oli ka loomulik keelt rohkem

\footnotetext{
${ }^{1}$ Info pärineb isiklikust kirjavahetusest Eesti Keele Instituudi vanemarvutilingvisti Ülle Viksiga (7. V 2020), sest ÕS 1999 ei ole veebis kättesaadav. ÕS 1999-s kasutatakse üheksa sõna tähenduse kohta ka märgendit !HV.SOB 'harva sobiv', millest ÕS 2006-s on mõnel juhul saanud sõnastus „ei soovita tähenduses”, teistel juhtudel on märge kaotatud.

${ }^{2}$ ÕS-is on palju eri rangusega soovitusi, mis samuti tähendusi piiravad, vt nt vormi avatud kohta sõnaartiklit avama (,[---] Avati uus kauplus, vrd kauplus on avatud, parem lahti 9-18. [---] Sageli on lahtine parem kui avamistoimingule viitav avatud"; ÕS 2018) ja soovituse tausta Saari 1976: 86.

${ }^{3}$ 1993. aastal tööd alustanud Emakeele Seltsi keeletoimkond võttis esimese tähendusi puudutava otsuse vastu 2009. aastal („Kaassõnade peale ja pärast tähenduse normimisest”). 2012. aastal arutati sõnade kompetents ja tolerants tähenduse laienemise üle, mille muutmisega ÕS 2013-s nõustuti, ning 2016. aastal arutati ühendverbi läbi viima üle, mille puhul tähendusmuutust paberliku stiili tõttu soovitatavaks ei peetud. Ülevaate keeletoimkonna otsustest ja aruteludest on kirjutanud Maire Raadik (2019).

${ }^{4}$ Keeletoimkonda kuuluvad küll ka ÕS-i toimetaja-koostaja Maire Raadik ning kohanimevalimiku ja hääldusjuhiste koostaja Peeter Päll, aga kõike ÕS-i sisusse puutuvat keeletoimkonnas läbi ei arutata.
} 
normida. Sajandi teisel poolel muutus kirjakeel aga põlvkondade kaupa järjest enam emakeeleks. (Kerge 2012) XXI sajandiks on eesti kirjakeel, mis on paljude üksikisikute ja inimrühmade teadliku tegevuse tulemus (Raag 2008: 22), muutunud stabiilseks ega vaja enam ranget ühtlustamist. Kuigi endiselt on vaja ka soovitusi, kuidas paremini ja selgemini väljenduda (Erelt 2000: 25), on kirjakeel siiski pidevas muutumises, mida keelekorraldus ei saa eirata (Kerge 2012). Seega tuleb soovitusi pidevalt ajakohastada (Erelt 1976: 23).

Artiklis annan ülevaate, kuidas on eesti keelekorralduses tegeliku keelekasutuse uurimist ja soovitustes arvestamist aja jooksul küll pooldatud, ent kuidas seda sõnatähenduste puhul tänapäeval siiski ei ole tehtud. Keskendun kasutuspõhise teooria ja korpusuuringute põhjal verbile vabandama, täpsemalt sellele, kuidas ühe keeleautoriteedi poole sajandi tagusest arvamusest endiselt kinni hoitakse, sest soovitust ei ole edaspidi uuritud. Tutvustan vabandama korpusanalüüsi tulemusi ning arutlen verbi tähendus- ja kasutusmuutuse üle.

\section{Keelest kasutuspõhise teooria pinnalt}

Eri aegadel on eri moodi suhtutud sellesse, mida keelena uurida ja kirjeldada: kui XX sajandi teisel poolel kirjeldati eesti keelena enamasti normitud kirjalikku keelt, siis tänapäeval koostatakse sõnastikke pigem keelekasutuse põhjal (Ross, Piits 2019: 686; vt ka Langemets jt 2018). Kuna keelesüsteem on väga lähedalt seotud kasutusega, siis on leitud, et keeleteooriad peaks uuringutes toetuma keele tegelikule kasutusele. Kasutuspõhise teooria põhiline uurimisobjekt ongi keel, mida inimesed päriselt loovad. Keelekasutus on keelesüsteemi toimimiseks ülioluline - kasutus on samal ajal nii keelesüsteemi tulem kui ka kujundab seda. (Barlow, Kemmer 2000: xv) Keel ei ole kindlaks määratud, vaid muutub ja on väga dünaamiline (Kaplan, Baldauf 1997: 41; Burridge, Bergs 2017: 13), sest keel ei muutu iseseisvalt, vaid inimeste kasutuses (Croft 2000: 4).

Kasutuspõhisuse mõiste võttis 1987. aastal kasutusele Ronald Langacker (vt Langacker 1987; ka Barlow, Kemmer 2000; Bybee 2010), aga sellise käsitluse järele on vajadus olnud juba varemgi. ${ }^{5}$ Näiteks Elmar Muuk loobus „Väikese õigekeelsussõnaraamatu" II ja III redaktsioonis (1936-1946) normingute liiga jäigast konstrueerimisest ning arvestas üha rohkem tegelikku keelekasutust võrreldes J. V. Veski „Eesti õigekeelsuse-sõnaraamatuga” (1925-1937) (Erelt 2007b: 13). Teiste seas on ka Elmar Elisto (1948: 99) soovinud, et kirjakeel oleks kooskõlas üldiselt kõneldava ühiskeelega. Ta on öelnud, et „edaspidisel keelekorraldamisel tuleb vist küll suuremal määral arvestada rahva ühiskeelt, kui seda on tehtud paaril eelmisel kümnendil [1940-ndail ja varem - L. R.], sest keel pole selleks, et soetada kauneid reegleid, küll aga on reeglid selleks, et soetada rahvale head keelt." Tegelikule keelekasutusele toetumisest tänapäeva sõnaraamatutöös on kirjutanud Langemets jt 2018; Tavast jt 2018.

${ }^{5}$ Juba Martin Lutheri (2000 [1530]: 88) järgi tuleb õiget keelt „küsida emalt kodus, lastelt tänaval, lihtrahvalt turuplatsil”. 
Eelnev ei tähenda, nagu ei saaks keelekasutuses vigu üldse olla. Keeleuurijad on teoretiseerinud selle üle, mis on keeleviga. Keeleveaks on peetud näiteks igasugust põhjendamatut hälbimust normikohasest kasutusest (Kull 1976: 26). Teisalt, keel varieerub ja teiseneb pidevalt, mispärast on arvatud ka, et keeles ei saa midagi loomulikku vigaseks pidada, sest kõik on õige just oma olemasolu tõttu (vt Rätsep 1976a: 124; Ross, Piits 2019: 687). Ent samal ajal ei saa kõike pidada üksnes normist kõrvalekaldeks, sest kui kirjutada arheoloogia asemel arheologja, siis on see ortograafiaviga (Hurtta 2006). Sellesse, et on olemas õige ja vale keelekasutus, usutakse üle maailma (Burridge, Bergs 2017: 21), ka Jaana Leinonen (2005) Soomes ja Arvi Tavast (2012) Eestis on seda arvamust täheldanud, ehkki ametlikult rõhutatakse soovituslikkust, mitte õiget-valet keelekasutust.

Objektiivne keelenorm muutub igas elavas keeles (Uuspõld 1976: 6). Suhtumine keele muutumisse on aga olnud erinev, näiteks Henn Saari pole olnud keelevigade suhtes kuigivorrd leplik. Ta on leidnud, et õigekeelsusallika norming ei peaks siiski keelekasutuse normile tingimusteta alluma. (Saari 1976: 14) Kuigi keel muutub pidevalt ja tegelikku keelekasutust tuleb uurida, et seda normimisel arvestada, on seni üks põlvkond eesti keele korraldajaid jätkanud eelmiste tööd ning see on viinud olukorrani, kus traditsioon on normimisel saanud mõjukaks kaasarääkijaks. Aga keelekorraldaja võib ka eksida, kui tal ei ole kasutada küllaldasi uurimisandmeid. (Uuspõld 1976: 6-8) Näiteks XX sajandi I poole kohta on Andrus Saareste (1952: 122) nentinud: „Õigeks kaldutakse pidama seda, mis on autoriteedi keelelisele maitsele vastavam." Niisiis võib keelekorraldaja tegevuses ette tulla vigu ja subjektiivsust (Kull 1976: 25; Raiet 1976: 152; Tauli 1968: 188), aga samuti on normingutel endal vigu, muu hulgas nende retrospektiivsus - need ei vasta tänapäeva keele normile, vaid on mingil määral kinni minevikus. Tiiu Erelt on öelnud, et normingud jäävad normist vahel liiga palju maha, need ei ole igavesed ning neid tuleb muuta keelenormi muutudes ja vananedes. (Erelt 1976: 22-23) Nagu Valter Tauli (1968: 188) on öelnud, oleks sünkroonsest seisukohast ideaalne, kui oleksid kindlad normid ja kõik neid aktsepteeriksid, aga diakroonsest seisukohast tähendaks keele igaveseks äranormimine keele ühe faasi fikseerimist, mis välistaks arengu.

Üks valdkond, kus ei ole võimalik keelt igaveseks ära normida, on sõnatähendused, sest need võivad väga kiiresti muutuda (Viks 1985: 72; McMahon 1999: 174). Järgmisena keskendungi sõnatähenduste normimise problemaatikale.

\section{Sõnatähendustest ja nende normimisest}

Ikka ja jälle on arvatud, et keelt peab korraldama ka semantilisest küljest (nt Veski 1967; Tauli 1968; Kindlam 1976; Saari 1976, 2004; Hurtta 2006; vastupidist arvamust vt Viks 1985: 72). Ent vahet tuleb teha üld- ja oskuskeelel. Kui oskuskeeles kõneldakse normivatest definitsioonidest ehk sellest, mida termin tähendama p e a b (Erelt 2007a: 55, Erelti rõhutus), siis üldkeeles pigem sellest, mis tähendus sõnal keelekasutuses on. Oskuskeele problemaatika jääb sellest artiklist välja, keskendun üldkeele sõnade tähendustele. 
Tähendusmuutusi kiputakse üldiselt rohkem tähele panema kui muid keelemuutusi (McMahon 1999: 174; Burridge, Bergs 2017: 21; Langemets jt 2018: 944), niisiis peab keelekorraldusel tähenduse muutumise kui igapäevase nähtuse kohta olema oma seisukoht (Tauli 1968: 111). Tähendusmuutusi ei saa uurida sõnade polüseemia ehk mitmetähenduslikkusega arvestamata (Traugott, Dasher 2002: 11). Peale polüseemia, mis oli näiteks J. V. Veskile pinnuks silmas - ta pidas seda pahenähtuseks keeles (Veski 1967: 333; Veski ja Aaviku vaidlust vt Langemets 2009: 16) -, ongi puristlikke grammatikuid häirinud sõna tähenduse muutumine ehk sõna kasutamine „vales” tähenduses (Tauli 1968: 110). Kuigi siiani on nii Eestis kui ka mujal maailmas arvatud, et igal sõnal on üks „õige” tähendus, siis tegelikult ongi sõnad enamasti polüseemsed, seepärast võivad nad ka suhteliselt kergesti tähendusi juurde saada või neid kaotada (McMahon 1999: 176-178; Traugott, Dasher 2002: 12). Valter Tauli (1968: 111) keelekorraldusteoorias on tähendusmuutus negatiivne siis, kui see ohustab selgust võimaliku kahemõttelisuse tõttu, mida võib põhjustada vana ja uue tähenduse korraga esinemine. Ent ükski uus tähendus ei asenda kohe eelmist, vaid uus ja vana tähendus eksisteerivad mõnda aega koos. Üksnes harva võib juhtuda, et vana tähendus kaob aja jooksul täiesti. (Traugott, Dasher 2002: 11; vt ka Koks 2002)

Sõna tähendus leitakse objektiivselt, jälgides sõnade tegelikku kasutust; (polüseemse) sõna tähenduse kohta on vajalik info järeldatav sellest, mida eelmises lauses teatati (Õim 1976: 127; vt ka Tavast 2012: 227-229). Kasutuspõhises teoorias rõhutataksegi konteksti olulisust: sõna tähendus ilmneb kontekstist ja kujuneb selle põhjal. Tavaline keelekasutaja mitmetähenduslikkuse üle ei juurdle, sest see teda enamasti ei häiri. (Cruse 1995: 16; Bybee 2010: 8; ka Tauli 1968: 111; Hint 1976: 141-142; Raiet 1976: 152)

Peale konteksti on kasutuspõhises teoorias oluline sõna esinemissagedus. Keeleüksuse või -mustri suurem sagedus põhjustab sügavamat juurdumist ehk kognitiivset tavapärastumist (Barlow, Kemmer 2000: xii). Sagedamini kasutatavad sõnad muutuvad rohkem ja kiiremini kui harvemini kasutatavad sõnad - mida sagedasem on sõna, seda lühemaks ta kulub. Lühenemist põhjustab ökonoomiataotlus, püüd anda infot edasi väikese energiakuluga. (Bybee 2010: 20, 39; Rätsep 1976: 117-118; Uuspõld 1976: 7)

Keelekasutuse analüüsimisel on oluliseks peetud korpusandmeid ehk kasutuspõhisust. Korpusandmed võivad anda vastuseid eri küsimustele, sealhulgas: „Millised üksused on keelesüsteemis kõige rohkem juurdunud?" (Barlow, Kemmer 2000: xv-xvi; vt ka Burridge, Bergs 2017: 254) Kuna keelemuutus on nii diakroonne kui ka sünkroonne protsess, võivad andmed tulla nii tänapäevastest korpustest, lähimineviku tekstikorpustest kui ka korpustest, kus on sajandeid vanad tekstid (Bybee 2010: 10; Barlow, Kemmer 2000: xviii).

Eesti keeleteadlased on aja jooksul samuti näinud vajadust uurida tegelikku keelekasutust (Elisto 1948; Erelt 1976; ka Tauli 1968, 1974; Habicht jt 2006; Tavast jt 2018), tekstikorpuse põhjal on koostatud uusim seletussõnaraamat (Langemets jt 2018; vt ka EKI ühendsõnastik 2020 Sõnaveebis). Pool sajandit tagasi rõhutas Rein Kull (1969: 645-646), et ÕS-i koostamise vajalikud tingimused on uurimisandmed kaasaegse eesti ühiskeele kohta ja korralikult põhjendatud keelekorraldusteooria. 
Valter Tauli keelekorraldusteooriat pidas Kull (1969: 646) liiga üldiseks, ehkki Tauligi (1974: 57) on öelnud, et kirjakeele korraldamine peab põhinema teaduslikul teoorial, korralikel põhimõtetel ja meetoditel. Kui 2019. aastal alustati Eesti Keele Instituudis ÕS-i info viimist sõnastiku- ja terminibaasisüsteemi Ekilex (mille info kajastub keeleportaalis Sõnaveeb; vt Koppel jt 2019), siis töörühma arutluste käigus sai selgeks, et ilma empiiriliste andmeteta pole võimalik ÕS 2018 tähendussoovituste üle otsustada. ${ }^{6}$

Tänapäeval on korpuste põhjal võimalik uurida (korrigeerimata) keeletarvitust nii varasema aja kui ka tänapäeva tekstides. See annab võimaluse hinnata tähendusmuutuse ulatust ja iseloomu, samuti vältida normingute mahajäämust keelekasutusest. Järgmisena analüüsin lähemalt üht ÕS-i probleemse tähendussoovituse juhtu, verbi vabandama. Näitan selle põhjal, et sõnatähenduste normimise alused eesti keelekorralduses tuleb üle vaadata - rohkem peab tegema ajakohaseid keeleuuringuid.

\section{Mis on viga verbil vabandama?}

EKI ühendsõnastikus 2020 (Sõnaveebis) on verbil vabandama kasutuse põhjal registreeritud kolm tähendust, kusjuures tähenduste esitamise järjekorras on arvestatud sagedust: 1) 'vabandust paluma', 2) 'õigustama' ja 3) 'andeks andma, andestama'. Samal ajal ei soovitata ÕS 2018-s seda kasutada tähenduses 'vabandust paluma'. Soovitus pärineb Henn Saarilt 1969. aastast (vt Saari 1976: 84-85, 87): vale tähendus 'vabandust paluma' pärineb ilmselt vene sõna извиняться vigasest tõlkest. ${ }^{7}$ Maire Raadik kordab Saari sõnu 1993. aastal, viitamata aga talle: „Sõna vabandama puhul on eksimisest hoidumiseks soovitatud eeskujuks võtta andeks andma" (Raadik, M. 1993). Esimest korda fikseeriti tähenduspiirang ÕS $1999-\mathrm{s},{ }^{8}$ hoolimata sellest, et 1980. aastal oli VÕK leidnud, et sagedasti kasutatavate üldkeelesõnade tähendusi ei saa ette kirjutada (Viks 1985: 72), ja uusi tähendusotsuseid polnud vastu võtnud ka 1993. aastal tegevust alustanud Emakeele Seltsi keeletoimkond. Uusimasse

\footnotetext{
${ }^{6}$ Kui EKÕS 1918 ilmumise eel töötati välja sõnaraamatu põhimõtted (Erelt 2007b: 6-7), siis ÕS 2018 põhineb ÕS 1999-1 - seda pole kasutuspõhiseid andmeid analüüsides läbinisti ajakohastatud. Ka Tiina Leemets, üks ÔS-ide 1999-2018 koostajatest, on nentinud, et ükski uus ÕS ei teki tühjale kohale ning tänini on ÕS-is jälgi Elmar Muugi ja teiste eelkäijate tööst (Koppel 2018). Seda kinnitavad ÕS-ide eessõnad: ÕS 1999-le on kõige rohkem aluseks olnud ÕS 1976 ja „Eesti kirjakeele seletussõnaraamat”, ÕS 2006 on ÕS 1999 uuendatud väljaanne ning ÕS 2013 ja ÕS 2018 on eelnevate täiendatud uustrükid.

${ }^{7}$ Henn Saari soovituse taga võib olla tollane ideoloogiline kord, kui „[t]eisenenud ideoloogilises õhkkonnas hakati avalikult arvustama ajakirjanduse puist, trafaretset ja ülespuhutud keeletarvitust ning halbu tõlkeid, peamiselt vene keelest" (Raag 2008: 247). Nõukogude ajal hoiti eesti keelt hoolikalt, sest „riigikukutamisele ei hakanud jõud peale ning keel andis pakitsevale energiale suhteliselt ohutu ja aktsepteeritud väljundi" (Tavast 2012: 232).

${ }^{8}$ Varasemates ÕS-ides leidub üksnes Elmar Muugi „Väikese õigekeelsus-sõnaraamatu” 5 . trükis (1940) vabandama järel nurksulgudes [kedagi, midagi, end] - tolles sõnaraamatus selgitavad nurksulud sõna tarvitusviisi lauses (Muuk 1940: 9), aga ei käsi-keela.
} 


\section{国 ÕS SOOVITAB}

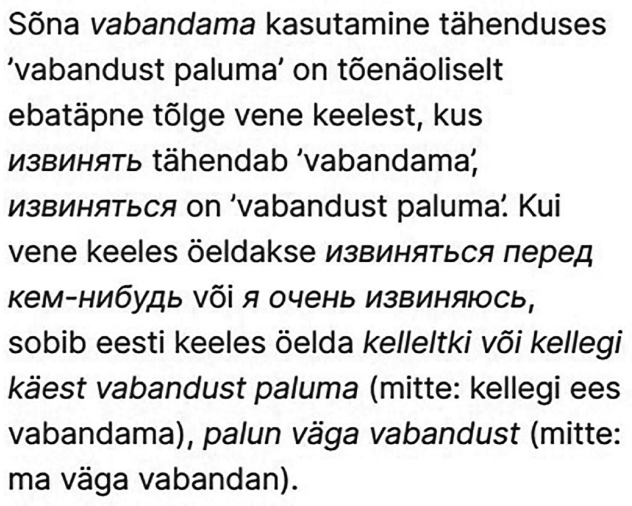

Joonis 1. ÕS-i soovitus verbi vabandama kohta Sõnaveebis 8. VI 2020 seisuga (EKI ühendsõnastik 2020).

keeleallikasse, EKI ühendsõnastikku 2020 Sõnaveebis, on samuti edasi kantud Maire Raadiku 1993. aasta sõnastus (vt joonist 1).

Selliseid vahendatud oletustel põhinevaid arvamusi on veelgi, nt Uno Liivaku (1978: 199) on leidnud, et ,asjad on segi läinud: süüdlased tihtipeale ei palu vabandust, vaid ütlevad, et nemad vabandavad, mille tagajärjel tekib keeleline mõttetus". Ka 2020. aastal antav soovitus toetub poole sajandi tagusele keeleautoriteedi ${ }^{9}$ arvamusele. Kuulun Henn Saari (1976: 87) sõnutsi ilmselt õigustuse otsijate hulka, kes räägivad „kujunenud väljendist, mis ei tekita arusaamatusi”. Arvan aga, et õigustusi oma seisukohtadele peavad otsima mõlemad pooled. Niisiis püüdsin seda „kujunenud väljendit" lähemalt analüüsida.

Kuna „Eesti etümoloogiasõnaraamatus” (ETÜ) verbi vabandama kohta infot ei ole, siis alustuseks küsisin Eesti Keele Instituudi etümoloogidelt, ${ }^{10}$ kust see sõna on eesti keelde tulnud. EKI etümoloogid kinnitasid, et vabandama on suhteliselt vana tuletis sõnast $v a b a$ ja seda kasutati juba XVII sajandi tekstides (vt mh Habicht jt 2015). Reet Kasik on kirjeldanud komplekssõnu, mida saab morfoloogiliselt analüüsida, ent mille tähendust ei saa tõlgendada moodustusosade leksikonitähenduste kaudu. Selliseks peab Kasik teiste seas verbi vabandama, sest tuletise vormilise alussõna tähendus on tähistatava mõiste komponendina ähmane: vabandama vrd vaba, vabanema. (Kasik 2015: 48) Etümoloogide hinnangul tähendas vabandama esialgu 'vabaks tegema, vabastama', millest arenes abstraktsem tähendus 'süüst, eksimusest vabastama. Vanades tekstides esineb enesekohane konstruktsioon ennast vabandama 'ennast (süüst) vabastama' ehk tänapäevaselt 'õigustama', mille kõrval mõningates kontekstides on võimalik ka tõlgendus tähenduses 'vabandust paluma'. Külli

\footnotetext{
${ }^{9}$ "Autoriteet tuleneb otseselt autoriteetsete isikute persoonist” (Isad 1990: 39).

${ }^{10}$ Isiklik kirjavahetus Meeli Sedriku ja Iris Metsmägiga (22. III 2020).
} 
Habichti ${ }^{11}$ sõnul oleneski verbi vabandama tähenduse tõlgendus konstruktsiooni 1) transitiivsusest: kedagi/midagi vabandama ehk keegi annab kellegi/millegi vabaks, vabastab kellegi/millegi (nt süüst, lauast) ehk tänapäevases tähenduses 'andeks andma, andestama'; või 2) enesekohasusest: end vabandama ehk keegi palub ennast (nt süüst) vabastada; vabaneb; tänapäevases tähenduses 'õigustama' või 'vabandust paluma'.

Ühtlasi on vabandama üks eesti keele labiilsetest verbidest. Petar Kehayovi ja Virve Vihmani eesti labiilsete verbide analüüsi üks lähtepunkte on eesti ja saksa keele pikk kontakt - saksa keeles on labiilseid verbe rikkalikult. Need on verbid, mis käituvad nii transitiivselt kui ka intransitiivselt ilma struktuurimuutuseta; labiilsus on transitiivse verbi intransitiivne kasutus. (Kehayov, Vihman 2014: 1061, 1091) Uurijate hüpotees on, et kuna enne XIX sajandit ilmunud tekste eesti keeles ja eesti keele kohta kirjutasid sakslased, siis on saksa keel mõjutanud oma labiilse süntaksiga eesti kirjakeelt. Kehayov ja Vihman ei jõudnud jälile, kui palju labiilseid verbe võis esimestest allikatest XVI sajandist kuni XX sajandini kasutusel olla, sest vana kirjakeele korpus ei ole eriti suur. Nende uurimuse kohaselt on aga selgeid tõendeid, et saksa emakeelega tõlkija tugines oma keelelisele intuitsioonile, kui valis, kas kasutada eesti verbi transitiivselt või intransitiivselt. Labiilne mall kanti saksa keelest eesti keelde üle ning saksamõjuline verbikasutus sagenes. Enamik Kehayovi ja Vihmani uuritud verbe on ta-tuletised (sh nda-tuletised, nagu on ka vabandama). (Kehayov, Vihman 2014: 1083-1084, 1088-1089)

Keelendi võõra päritolu ja võõrmõjulisuse argument on küll ÕS-i soovituste üks põhilisi aspekte - ka verbi vabandama tähendussoovituse puhul -, ent näiteks Valter Tauli (1974: 65) on kirjutanud, et efektiivsuse vaatenurgast pole väljendi päritolu esmaoluline. Järgmisena kirjeldangi verbi vabandama korpusanalüüsi tulemusi, et anda ülevaade, millistes tähendustes on seda verbi aja jooksul kasutatud ning tänapäeval kasutatakse.

\section{Verbi vabandama analüüsi materjal ja meetod}

Verbi vabandama kasutusest ja võimalikust tähendusmuutusest ülevaate saamiseks analüüsisin eri ajastute korpuste andmeid, nagu Joan Bybee (2010: 10) on kasulikuks pidanud. Kasutasin vana kirjakeele korpust (VAKK; Prillop 2013), DIGAR-i Eesti artikleid (abivahendiga Tinits 2020), eesti kirjakeele korpust 1890-1990 (TÜKK; Hennoste 1996) ning Sketch Engine'i kaudu eesti keele ühendkorpust 2017 ja 2019 (Kallas, Koppel 2018; Kallas, Koppel 2020; vt ka Kilgarriff jt 2004). Vanade tekstide korpustes ei esine loomulik keelekasutus samal määral kui tänapäevaste tekstide ühendkorpustes, sest vanad tekstid on pärit toimetatud allikatest, ühendkorpuse tekstid aga suurel määral mitte (vt Kallas, Koppel 2018).

Kitsendasin uurimuse verbi vabandama pöördeliste vormide kasutuse peale, sest soovitus puudutab verbi ning käänd- ja määrsõnalises vormis on sel kindlaks

${ }^{11}$ Isiklik kirjavahetus Külli Habichtiga (16. III 2020). 
kujunenud tähendused, nt vabandavalt 'andestust paluvalt; selgitust, õigustust esitavalt'. Lisaks ei arvestanud ma verbina des-vormi, sest seda kasutatakse määrsõnalaadsena (EKK: 231), nt Naeratades ja vabandades korjasin paberi üles. Peale algvormi vabandama arvestasin infiniitsetest vormidest $d a$-infinitiivi, sest see väljendab tegevust (EKK: 232). Kõrvale jätsin ka kindla tähendusega ühendverbid välja vabandama 'õigustama' ja ette vabandama 'enne millegi toimumist vabandust paluma'.

Analüüsisin verbi vabandama kasutust igas korpuses kolme tänapäevase tähenduse järgi: 1) 'vabandust paluma', 2) 'õigustama', 3) 'andeks andma, andestama'. Kus võimalik, vaatlesin näiteid ajalises järgnevuses kümnendite kaupa. Igal korpusel on omad eelised ja probleemid, mida kirjeldan vastava korpuse juures.

\section{XVII-XIX sajand. Vana kirjakeele korpus (VAKK)}

Vana kirjakeele korpuses leidub verbi vabandama andmeid aastate 1632-1889 kohta. Korpus ei ole paraku kuigi suur (2,7 mln eesti sõnet) ja selle XIX sajandi osas on ülekaalus käsikirjalised kohtuprotokollid (vt Kingisepp jt 2004), ent see korpus annab siiski läbilõike perioodi olulisimatest tekstidest. Otsingukriteeriumidele vastas VAKK-is 119 verbi vabandama vormi. Korpuse tekstid sisaldavad sellele ajastule iseloomulikku keelekasutust. Analüüsitulemused võtab kokku tabel 1.

Tabel 1. Verbi vabandama tähendused XVII-XIX sajandil.

\begin{tabular}{|l|l|l|l|l|}
\hline Sajand & $\begin{array}{l}\text { 'vabandust } \\
\text { paluma' }\end{array}$ & 'óigustama' & $\begin{array}{l}\text { 'andeks andma, } \\
\text { andestama' }\end{array}$ & Lauseid kokku \\
\hline XVII & $3(21,4 \%)$ & $7(50 \%)$ & $4(28,6 \%)$ & 14 \\
\hline XVIII & 0 & $17(89,5 \%)$ & $2(10,5 \%)$ & 19 \\
\hline XIX & $1(1,2 \%)$ & $84(97,7 \%)$ & $1(1,2 \%)$ & 86 \\
\hline Kokku & $4(3,4 \%)$ & $108(90,8 \%)$ & $7(5,9 \%)$ & 119 \\
\hline
\end{tabular}

Valimi seitsmes lauses esineb transitiivne konstruktsioon kedagi vabandama tähenduses '(kellelegi) andeks andma, andestama', nt Minna ollen ühhe Pöldo otsnud / ja pean wälja minnema / ja sedda waatma / ma pallun sind / wabbanda mind. Tähenduses 'õigustama' esineb enesekohane konstruktsioon end vabandama ja ka intransitiivne vabandama enamasti XIX sajandi kohtuprotokollides (86 lausest 83 lauses, millest 60 lauses intransitiivselt), kus süüalune püüab end süüst vabastada, nt Jaan Malmberg ei saa ennast vabandada, vaid peab ennast süidlaseks tunnistama. On ka religioosse sisuga tekste XVII-XVIII sajandist, nt Heinrich Stahlilt ja Friedrich Gustav Arveliuselt, milles võib näha tähendust 'õigustama': Kül nüüd waese mehhe louad wärrisesid: ja ta tahtis ennast wabbandada, et keik äppardus külma sü̈ olli.

Leidub siiski neli lauset (näited 1-2), milles enesekohane konstruktsioon end vabandama esineb tähenduses 'end vabastada paluma' ehk mida tänapäevases mõttes võiks tõlgendada tähendusena 'vabandust paluma'. 
(1) Nemmat agkas õ̃at hend wabbandanut / ninck mitte tulla tachtnut. (1649, Stahl)

(2) Margus Kitsing olli tännases päevas kolmas kõrd selle kohtu ette sellen asjan kutsutu ja nimelt temale üttelda lastu, et kui temma tänna kohtu ette ei tulle saab kohus ärra moistma ent siiski es olle temma tänan kohtu ette tullnu ei ka henast vabandata lasknu. (1884, kohtuprotokoll)

Nelja lause põhjal, millest kolm on pärit Heinrich Stahlilt ja üks XIX sajandi lõpust, ei ole võimalik tähenduse 'vabandust paluma' kohta üldistusi teha. On aga näha, et „vale” tähendus ilmneb juba üsna varasel ajal ja Stahlil ilmselt tema saksa keele tausta pärast (vt Kasik 2011: 26-29).

Kokkuvõttes esineb nende andmete põhjal XVII-XIX sajandil kõige rohkem tähendust 'õigustama' (108 lauses, 90,8\%), vähem esineb tähendust 'andeks andma, andestama' (7 lauses, 5,9\%). Pisut esineb konteksti põhjal tõlgendades ka tähendust 'vabandust paluma' (4 lauses, 3,4\%), mis on konstruktsiooniliselt seotud tähendusega 'õigustama' (end vabandama). Tähenduses 'andeks andma, andestama' kasutatakse transitiivset konstruktsiooni kedagi/midagi (XVII sajandi tekstides ka kellegi/ millegi) vabandama. Tähenduses 'õigustama' on kasutusel enesekohane konstruktsioon end vabandama ja ka intransitiivne vabandama. Enesekohane konstruktsioon esineb mõnevõrra ka tähenduses 'vabandust paluma'. Paraku ei ole VAKK-is piisavalt palju eri aegadest pärit lauseid, et oleks näha, millal täpsemalt tuli tähendus 'vabandust paluma' keelekasutuses suuremal määral tähenduse 'õigustama' kõrvale.

\section{0.-1930. aastad. DIGAR-i Eesti artiklid}

DIGAR-i Eesti artiklid sisaldavad ajakirjandustekste (sh nendes ilmunud ilukirjandustõlkeid). Korpus on küllaltki mahukas, eriti 1850.-1930. aastate kohta, Teise maailmasõja ja nõukogudeaegseid tekste selles korpuses suuresti ei esine. ${ }^{12}$ Korpuse tekstid on osaliselt toimetatud, neis ei esine päris korrigeerimata keelekasutust. Tärktuvastatud tekstid on sageli üsna mõistetamatult digiteeritud, seepärast olen näitelausetes kirjapilti kohendanud, et lause oleks arusaadav. Kuna otsingu piirang oli 100 tähemärki konteksti vasakult ja paremalt, siis on mõned näitelaused poolikud.

Otsisin sõna vabandama esinemist kuni 1939. aastani. Algusaasta piirangut ma ei seadnud, et leida võimalikult varaseid vasteid. Varaseim kasutusjuht ilmnes aastast 1872, sest 1870. aastatel muutus uus kirjaviis üldkasutatavaks (Päll 2019). Vanas kirjaviisis (wabbandama) verbivasteid ma ei otsinud, sest muidu oleks andmete maht läinud üüratult suureks.

Kuna alles aastail 1919-1920 otsustas Eesti Kirjanduse Seltsi keeletoimkond w-tähe asemel kasutada $v$-d (Päll 2005: 66), siis analüüsisin nii $w$ - kui ka $v$-tähega vabandama pöördelisi vorme. Andmeid erisuguste vabandamisega seotud sõnade kohta sain üle 20 000, mistõttu kitsendasin $w$-ga wabandama valimit järgmiselt: 1) algvorm wabandama, 2) oleviku kindel kõneviis ainsuses ja mitmuses (waban-

\footnotetext{
${ }^{12}$ Esineb küll mõningaid Välis-Eesti tekste, aga neid ei saa siin analüüsis arvestada, sest need ei
} kajasta Eestis elanud eestlaste keelekasutust. 
dan, wabandad, wabandab, wabandame, wabandate, wabandavad); 3) lihtmineviku kindel kõneviis ainsuses ja mitmuses (wabandasin, wabandasid (2. sg), wabandas, wabandasime, wabandasite, wabandasid (3. pl)), 4) käskiv kõneviis (wabanda, wabandage). $v$-tähega vabandama kohta vaatasin 500 pöördelise vormi juhuvalimit. Kuna vormi vabandage esines 1920.-1930. aastatel väga palju, piirasin selle esinemuse valimis mõlemal kümnendil 500 lausega. Teisi vorme sama palju ei esinenud. Kokku analüüsisin sellest korpusest 6812 lauset. Analüüsitulemused võtab kokku tabel 2. Analüüsisin XIX sajandi lõpukümnendeid koos, sest näiteid esines suhteliselt vähem. XX sajandi materjali esitan kümnendite kaupa.

Tabel 2. Verbi vabandama tähendused kümnendite kaupa 1870.-1930. aastatel.

\begin{tabular}{|l|l|l|l|l|}
\hline Kümnend & $\begin{array}{l}\text { 'vabandust } \\
\text { paluma' }\end{array}$ & 'õigustama' & $\begin{array}{l}\text { 'andeks andma, } \\
\text { andestama' }\end{array}$ & Lauseid kokku \\
\hline $1872-1899$ & $184(20,2 \%)$ & $332(36,5 \%)$ & $393(43,2 \%)$ & 909 \\
\hline $1900-1909$ & $140(17,3 \%)$ & $192(23,7 \%)$ & $478(59 \%)$ & 810 \\
\hline $1910-1919$ & $167(21,7 \%)$ & $291(37,8 \%)$ & $311(40,4 \%)$ & 769 \\
\hline $1920-1929$ & $525(31 \%)$ & $370(21,8 \%)$ & $800(47,2 \%)$ & 1695 \\
\hline $1930-1939$ & $1086(41,3 \%)$ & $490(18,6 \%)$ & $1053(40,1 \%)$ & 2629 \\
\hline Kokku & $2102(30,9 \%)$ & $1675(24,6 \%)$ & $3035(44,6 \%)$ & 6812 \\
\hline
\end{tabular}

Valimi järgi kasutati verbi vabandama enne XX sajandit tähenduses 'vabandust paluma' osakaaluga 20,2\%. Varaseim lause, milles verbi sellise kasutuse tuvastasin, pärineb 1873. aastast (näide 3). Kasutus püsis XX sajandi esimestel kümnenditel samas suurusjärgus, kuni hakkas 1920-ndatel kasvama. 1930. aastate jooksul kasvas tähenduses 'vabandust paluma' kasutus 41,3\%-ni. Seega kasutati verbi vabandama tähenduses 'vabandust paluma' 1939. aastaks kaks korda rohkem kui enne 1920. aastat.

(3) Ta oli kül üht sugulast Nooina linna saatnud, ennast sääl wabandama, aga see on paawsti weel enam wihastanud kui waigistanud. (1873)

Verbi kasutus tähenduses 'õigustama' vähenes analüüsitud perioodil poole võrra: kui enne XX sajandit oli kasutus 36,5\%, siis 1930-ndatel kasutati verbi selles tähenduses $18,6 \%$. See on ootuspärane, sest sama konstruktsiooni end vabandama kasutati kahe tähenduse jaoks, nii 'vabandust paluma' kui ka 'õigustama', ja kui ühe tähenduse kasutus sagenes, siis teise oma vähenes. Valimi põhjal ei ole võimalik öelda, millal ja miks tuli tähenduse 'õigustama' kohta kasutusele väljend välja vabandama.

Tähenduses 'andeks andma, andestama' kasutati verbi vabandama analüüsitud perioodil stabiilselt palju: enne XX sajandit $43,2 \%$ ja 1930 -ndatel $40,1 \%$. Tähelepanuväärne on, et kui XX sajandi eel kasutati verbi tähenduses 'andeks andma, andestama' kaks korda rohkem kui tähenduses 'vabandust paluma' (vastavalt 43,2\% ja 20,2\%), siis 1930-ndatel tähenduste kasutus võrdsustus (vastavalt 40,1\% ja 41,3\%). Kui käskivas kõneviisis on verbi tähendus enamasti 'andeks andma, andestama' (näide 4), siis keelavas kontekstis kipub käskiva kõneviisi tähendus olema 'vabandust paluma' (näited 5,6) või 'õigustama' (näide 7). 
(4) Wabandage, kahetsen wäga [---]. (1904)

(5) „Oh, ärge ennast wabandage,” wastas Müller, „sest pole midagi. [---] (1896)

(6) „Oo, ära wabanda," ütlesin ma, „kuid ole tulewikus ettewaatlikum.” (1926)

(7) Hankige jõuluks sõpradele ja teenijatele raamatuid ja ärge sellega wabandage, et soowitawaid nendest saada ei ole. (1902)

Transitiivse ja enesekohase kasutuse kõrval esineb sellelgi perioodil verbi intransitiivset ja ilma enesekohase asesõnata kasutust, kusjuures nii tähenduses 'õigustama' (näide 8) kui ka 'vabandust paluma' (näited 9, 10).

(8) On nad rumalad, sõnakuulmatumad, laisad, joodikud ja ööhulkujad, siis wabandawad maaemad: tema on kitsa mõistusega, suure südamega, hoolimata meelega [---]. (1874)

(9) Kirjasaatja wabandab, et ta tarkadest meestest niiwiisi kirjutada on julgenud [---]. (1910)

(10) Nii lubamatu kui ka see ei ole, teatri mängu wõrrelda kinoga, ma wabandan, ja teen seda siiski. (1924)

Kokkuvõttes kasvas perioodil 1872-1939 verbi vabandama kasutus tähenduses 'vabandust paluma' järk-järgult ning selle osakaal kahekordistus 20,2\%-lt XIX sajandi lõpus 41,3\%-ni 1930. aastate lõpuks. Tähenduse 'õigustama' kasutus vähenes sellest tulenedes poole võrra (36,5\%-lt 18,6\%-ni), sest enesekohast konstruktsiooni end vabandama sai tõlgendada kahes tähenduses: kui ühe tähenduse kasutus sagenes, siis teise oma vähenes. Kuna tähenduse 'andeks andma, andestama' jaoks kasutati transitiivset konstruktsiooni kedagi/midagi vabandama, siis jäi verbi selles tähenduses kasutus vaadeldud perioodil stabiilseks, vastavalt $43,2 \%$ ja 40,1\%. Endiselt kasutati verbi transitiivselt ja enesekohaselt, aga aina rohkem kasutati seda ka intransitiivselt ja ilma enesekohase asesõnata.

\section{0.-1990. aastad. Eesti kirjakeele korpus 1890-1990 (TÜKK)}

Eesti kirjakeele korpuses 1890-1990 ei ole 1940. aastate materjali, seega analüüsisin perioodi 1950.-1990. aastad. Korpus ei ole eriti suur (valitud perioodi kohta on ligi 3 miljonit sõna) ${ }_{,}^{13}$ aga aastate $1940-1990$ kohta polegi Eestis veel põhjalikku korpust. Otsingukriteeriumidele vastas korpuses 106 verbi vabandama pöördelist vormi. Korpus sisaldab peamiselt ilu- ja ajakirjandustekste, mistõttu on tekstid suurel määral toimetatud ning korrigeerimata keelekasutust esineb neis vähe. Analüüsitulemused võtab kokku tabel 3.

\footnotetext{
${ }^{13}$ Korpuse allikaviiteid ma ei arvestanud, sest esiteks pidanuks iga allika ilmumisaasta ise üles otsima ja see olnuks väga ajakulukas ning teiseks olid paljud allikad pärit hoopis 2000. aastatest, aga XXI sajandi tekstide kohta on ühendkorpustes palju mahukam materjal.
} 
Tabel 3. Verbi vabandama tähendused kümnendite kaupa 1950.-1990. aastatel.

\begin{tabular}{|l|l|l|l|l|}
\hline Kümnend & $\begin{array}{l}\text { 'vabandust } \\
\text { paluma' }\end{array}$ & 'õigustama' & $\begin{array}{l}\text { 'andeks andma, } \\
\text { andestama' }\end{array}$ & Lauseid kokku \\
\hline $1950-1959$ & $1(33,3 \%)$ & $1(33,3 \%)$ & $1(33,3 \%)$ & 3 \\
\hline $1960-1969$ & $7(58,3 \%)$ & $5(41,7 \%)$ & 0 & 12 \\
\hline $1970-1979$ & $7(38,9 \%)$ & $6(33,3 \%)$ & $5(27,8 \%)$ & 18 \\
\hline $1980-1989$ & $7(50 \%)$ & $3(21,4 \%)$ & $4(28,6 \%)$ & 14 \\
\hline $1990-1999$ & $41(69,5 \%)$ & $10(16,9 \%)$ & $8(13,6 \%)$ & 59 \\
\hline Kokku & $63(59,4 \%)$ & $25(23,6 \%)$ & $18(17 \%)$ & 106 \\
\hline
\end{tabular}

1950. aastaid ei saa kolme tulemuse põhjal analüüsida. 1960. aastatel esinevad tähendused 'vabandust paluma' ja 'õigustama' enam-vähem võrdselt, tähendust 'andeks andma, andestama' ei leidunud. 1970. aastatel on näha kõigi kolme tähenduse suhteliselt võrdset esinemist (5-7 lauset), ent 1980. aastatel esineb tähendust 'vabandust paluma' sama palju kui tähendusi 'õigustama' ja 'andeks andma, andestama' kokku (7 vs. 3-4 lauset). 1990. aastatel esineb tähendust 'vabandust paluma' üle kahe korra rohkem kui teisi tähendusi kokku (41 vs. 18 lauset).

Kuigi endiselt esineb verbi vabandama kasutus transitiivses (näide 11, 'andeks andma, andestama'; kokku 3 lauses) ja enesekohases konstruktsioonis (näide 12, 'õigustama'; kokku 8 lauses), siis üha enam süveneb intransitiivne ja enesekohase asesõnata kasutus (näide 13, 'vabandust paluma'; kokku 95 lauses).

(11) Te vabandate mind, et ma siin istun? (ILU 1970)

(12) Meie, arstid, püüame endid selliste kaebuste puhul vabandada tavaliselt ajapuudusega. (AJA 1960)

(13) Tulin külgkardinate vahelt nähtavale, teretasin ja vabandasin. (ILU 1980)

Nappide andmete põhjal on siiski näha, et 1990. aastateks on tähendus 'vabandust paluma' saanud suurema osakaalu kui tähendused 'õigustama' ja 'andeks andma, andestama' (vastavalt 69,5\%, 16,9\% ja 13,6\%). Kui 1930. aastate lõpuks oli tähenduse 'vabandust paluma' kasutus tõusnud 41,3\%-ni, siis järgmistel kümnenditel see areng süvenes - tabelist on näha, et igal kümnendil kasvas verbi tähenduses 'vabandust paluma' kasutus pidevalt, jõudes 1990-ndatel 69,5\%-ni. Sellises tähenduses kasutuse süvenemine on seotud ka verbi sagenenud intransitiivse ja ilma enesekohase asesõnata kasutamisega, mida toetab keele ökonoomiataotlus (Bybee 2010: 20) ning sõnatähenduse selgus kontekstis (Cruse 1995: 16). Pole küll välistatud, et verbi vabandama sagedasem intransitiivne ja enesekohase asesõnata kasutus tähenduses 'vabandust paluma' on ka vene keelest mõjutatud, nagu Henn Saari arvas, ent see ei ole tänapäeva kasutuskontekstis oluline põhjus tähendust 'vabandust paluma' ebasoovitatavaks pidada. 


\section{XXI sajand. Eesti keele ühendkorpus 2017 ja 2019}

Eesti keele ühendkorpusele 2017 ja 2019 pääseb ligi korpusprogrammi Sketch Engine (vt ka Kilgarriff jt 2004) kaudu, mis võimaldab võrreldes teiste korpustega teha detailsemaid otsinguid. Ühendkorpused on väga suured: 2017. aasta korpus sisaldab 1,1 miljardit sõna ja 2019. aasta oma 1,5 miljardit sõna. Nendes korpustes on palju korrigeerimata tekste, nii annavad need hea ülevaate toimetamata keelekasutusest. Minu valim on juhuslik, nii ei ole tekstid kallutatud mõne ajavahemiku või tekstitüübi poole.

Saamaks verbi tänapäevasest kasutusest detailsemat ülevaadet, analüüsisin eraldi 1) algvormi vabandama; 2) oleviku kindlat kõneviisi ainsuses ja mitmuses (vabandan, vabandad, vabandab, vabandame, vabandate, vabandavad);3) lihtmineviku kindlat kõneviisi ainsuses ja mitmuses (vabandasin, vabandasid (2. sg), vabandas, vabandasime, vabandasite, vabandasid (3. pl)); 4) käskivat kõneviisi (vabanda, vabandage); 5) muude vormide 500 lause juhuvalimit.

Kuna ühendkorpus 2019 avalikustati 30. IV 2020, aga mina alustasin uurimistööd palju varem, põhineb enamik minu analüüsist ühendkorpusel 2017. Verbi vabandama esineb 2017. aasta korpuses 46059 korda, seega seadsin iga vormi puhul analüüsitavate lausete piirarvuks 500 (kõiki nii palju ei esinenudki). Rakendasin korduvalt funktsiooni „Shuffle”, et tulemused oleksid juhuslikud ja pärit korpuse eri osadest. Kuna 2017. aasta seisuga võrreldes ei olnud põhjust eeldada, et verbi kasutus oleks kuigi palju muutunud, analüüsisin 2019. aasta korpusest 500 pöördelise verbivormi juhuvalimit (uues korpuses esineb verbi vabandama 68921 korda). Kokku analüüsisin tänapäevase kasutuse kohta 6211 lauset. Ühendkorpuse 2017 ja 2019 analüüsitulemused võtab kokku tabel 4.

Tabel 4. Verbi vabandama tähendused ühendkorpuses 2017 ja 2019.

\begin{tabular}{|l|l|l|c|l|}
\hline Ühendkorpus & $\begin{array}{l}\text { 'vabandust } \\
\text { paluma' }\end{array}$ & 'õigustama' & $\begin{array}{l}\text { 'andeks andma, } \\
\text { andestama' }\end{array}$ & Lauseid kokku \\
\hline 2017 & $4144(72,6 \%)$ & $578(10,1 \%)$ & $989(17,3 \%)$ & 5711 \\
\hline 2019 & $407(81,4 \%)$ & $19(3,8 \%)$ & $74(14,8 \%)$ & 500 \\
\hline Kokku & $4551(73,3 \%)$ & $597(9,6 \%)$ & $1063(17,1 \%)$ & 6211 \\
\hline
\end{tabular}

Tabelist 4 on näha, et XXI sajandil kasutatakse verbi vabandama enamasti tähenduses 'vabandust paluma' (73,3\%). Tähenduse 'õigustama' kasutus on vähene (9,6\%) - selle taga võib olla põhjus, et palju kasutatakse nii verbi õigustama ennast kui ka väljendit välja vabandama (ühendkorpuses 2019 vastavalt 85993 ja ligikaudu 1700 esinemisjuhtu). Tähendust 'andeks andma, andestama' esineb palju vähem kui tähendust 'vabandust paluma' (17,1\% vs. $73,3 \%)$. Endiselt on näha verbi transitiivset ja enesekohast kasutust, aga enamasti kasutatakse verbi intransitiivselt ja ilma enesekohase asesõnata. Detailsema ülevaate verbi tänapäevasest kasutusest ühendkorpuse 2017 põhjal annab tabel 5.

Tabelist 5 on näha, et verbi vabandama kasutatakse valdavalt tähenduses 'vabandust paluma'. Kõige rohkem esineb see kindla kõneviisi oleviku mina-vormis 
vabandan (99,8\%) ja meie-vormis vabandame (99,2\%), nt Vabandan veelkord ja ärge pikka viha pidage; Vabandame selle tõttu tekkinud ebameeldivuste pärast. Samuti vastavates lihtmineviku vormides (vastavalt $91,4 \%$ ja 94,9\%). Algvormi vabandama kasutatakse tähenduses 'vabandust paluma' $92,6 \%-1$ juhtudest. Muudes vormides on verbi kasutus 75\%-1 juhtudest tähenduses 'vabandust paluma'. Üksnes käskivas kõneviisis (vabanda, vabandage) ja vormis vabandate jääb selle tähenduse kasutus alla 50\%, sealjuures eriti vähe kasutatakse tähendust 'vabandust paluma' käskiva kõneviisi mitmuse vabandage korral $(0,6 \%)$, nimelt ühes lauses kontekstis Te olete vanemaealiste suhtes ksenofoobiline. Vabandage ja kiiresti.

Tabel 5. Verbi vabandama tähendused eri vormide kaupa ühendkorpuses 2017.

\begin{tabular}{|l|c|c|c|c|}
\hline Vorm & $\begin{array}{l}\text { 'vabandust } \\
\text { paluma' }\end{array}$ & 'óigustama' & $\begin{array}{l}\text { 'andeks andma, } \\
\text { andestama' }\end{array}$ & Lauseid kokku \\
\hline vabandama & $463(92,6 \%)$ & $35(7 \%)$ & $2(0,4 \%)$ & 500 \\
\hline vabandan & $499(99,8 \%)$ & $1(0,2 \%)$ & 0 & 500 \\
\hline vabandad & $155(84,7 \%)$ & $16(8,7 \%)$ & $12(6,6 \%)$ & 183 \\
\hline vabandab & $389(77,8 \%)$ & $103(20,6 \%)$ & $8(1,6 \%)$ & 500 \\
\hline vabandame & $496(99,2 \%)$ & $1(0,2 \%)$ & $3(0,6 \%)$ & 500 \\
\hline vabandate & $24(44,4 \%)$ & $6(11,1 \%)$ & $23(42,6 \%)$ & 53 \\
\hline vabandavad & $336(69,1 \%)$ & $134(27,6 \%)$ & $16(3,3 \%)$ & 486 \\
\hline vabandasin & $457(91,4 \%)$ & $35(7 \%)$ & $8(1,6 \%)$ & 500 \\
\hline vabandasid $(2 . \mathrm{sg})$ & $29(96,7 \%)$ & $1(3,3 \%)$ & 0 & 30 \\
\hline vabandas & $429(85,8 \%)$ & $69(13,8 \%)$ & $2(0,4 \%)$ & 500 \\
\hline vabandasime & $75(94,9 \%)$ & $4(5,1 \%)$ & 0 & 79 \\
\hline vabandasite & $9(81,8 \%)$ & $1(9,1 \%)$ & $1(9,1 \%)$ & 11 \\
\hline vabandasid $(3 . \mathrm{pl})$ & $300(81,3 \%)$ & $69(18,7 \%)$ & 0 & 369 \\
\hline vabanda & $105(21 \%)$ & $6(1,2 \%)$ & $389(77,8 \%)$ & 500 \\
\hline vabandage & $3(0,6 \%)$ & 0 & $497(99,4 \%)$ & 500 \\
\hline Muud vormid & $375(75 \%)$ & $97(19,4 \%)$ & $28(5,6 \%)$ & 500 \\
\hline Kokku & $4144(72,6 \%)$ & $578(10,1 \%)$ & $989(17,3 \%)$ & 5711 \\
\hline
\end{tabular}

Tähenduses 'õigustama' kasutatakse verbi vähe, keskmiselt 10,1\% koguvalimist. Enim kasutatakse seda tähendust vormides vabandavad $(27,6 \%)$ ja vabandab $(20,6 \%)$, nt Tean, et pole hea toon tuua näidet omaenda loomingust, kuid vabandab ehk see, et ta on veel trükikojas; Raja lõhkumist vabandavad nad teadmatusega, kuna keelumärgid puuduvad. Vähim kasutatakse tähendust 'õigustama' vormides vabandan $(0,2 \%)$, vabandame $(0,2 \%)$ ja vabandage (0\%). Näiteks lauses Nii kaua, kui vabandame ja õigustame oma leigust ja pattu, ei saa meeleparandus tulla.

Tähenduses 'andeks andma, andestama' kasutatakse enim käskiva kõneviisi mitmuse vormi vabandage $(99,4 \%)$ ja ainsuse vormi vabanda $(77,8 \%)$. Vormi vabanda korral on märkimisväärne ambivalentsem kasutus võrreldes mitmusevormiga vabandage, 21\%-1 juhtudest esineb ka tähendus 'vabandust paluma', nt Vabanda 
viisakalt ja lõpeta kõne. Vormi vabandate puhul on tähenduste 'vabandust paluma' ja 'andeks andma, andestama' kasutus suhteliselt võrdne, vastavalt 44,4\% ja 42,6\%. $\mathrm{Nt} \mathrm{Ma}$ loodan, et te vabandate mind, kui ma toon mõned väikesed isiklikud näited ('andeks andma, andestama'); Seetõttu pean vajalikuks, et vabandate riigi nimel minu ees! ('vabandust paluma').

Tõestust leidis, et käskiva kõneviisi vorme vabanda ja vabandage kasutatakse verbilise tarvituse kõrval suuresti nii algatus- kui ka reaktsioonikiiluna. Algatuskiilud on käskiva või kindla kõneviisi teise isiku verbivormid, mille verbiline tähendus on tagaplaanil või kadunud, ehkki neis on säilinud ainsuse-mitmuse eristus. Reaktsioonikiilud on partiklid, harvemini ka kinnisüksused. (Hennoste 2017: 495-496) Nt Vabandage, kas te olete elus?; Ja see, vabandage, on ülbus. Samamoodi kasutatakse valmisüksusena ka vorme vabandan ja vabandame, mis on kasutamiseks ökonoomselt lühikesed võrreldes konstruktsiooniga palun/palume vabandust.

Tänu kontekstile ei jänud üheski lauses arusaamatuks, kas verbi kasutati vastupidistes tähendustes 'vabandust paluma' või 'andeks andma, andestama'; ei tekkinud „keelelist mõttetust” (Liivaku 1978: 199). Transitiivset konstruktsiooni kedagi/ midagi vabandama ja enesekohast end vabandama esineb küll endiselt, aga võrreldes intransitiivse ja ilma enesekohase asesõnata kasutusega märkimisväärselt vähem. Nt Kui nii, siis - vabandage mind - rullsuusatajate koht ei ole üldkasutataval kergliiklusteel ning Vabandasime end ette ja taha, et nii hiljaks jäime.

Kahe ühendkorpuse analüüsitulemuste põhjal võib kokkuvõttes öelda, et verbi vabandama kasutatakse XXI sajandi valimis tähenduses 'vabandust paluma' 73,3\%-1 juhtudest. Ülejäänud veerandi kasutusest moodustavad tähendused 'andeks andma, andestama' (17,1\%) ja 'õigustama' (9,6\%). Enamasti kasutatakse verbi intransitiivselt ja ilma enesekohase asesõnata, kuigi kadunud pole ka transitiivne ja enesekohane kasutus.

\section{Diskussioon}

Eelnevat üldistades on õigustuse otsija „kujunenud väljendile” õigustuse ka leidnud, sest eri sajandeid hõlmavate korpuste analüüsist on näha, et verbi vabandama kasutus tähenduses 'vabandust paluma' ilmneb võimaliku tõlgendusena juba XVII sajandil (kolmes lauses). Selle tähenduse sagedasemat kasutust on näha XIX sajandi lõpukümnendeil $(20,2 \%)$ ning selle osakaal suurenes aja jooksul pidevalt, jõudes XXI sajandil 73,3\%-ni. Tähelepanuväärne on tõik, et 1930. aastatel oli sellise kasutuse osakaal jõudnud 41,3\%-ni. Paraku pole nõukogude aja kohta suurt korpust, et teada saada, millal sai tähenduse 'vabandust paluma' kasutus valdavaks ja kas see toimus järk-järgult või hüppeliselt. See pole siiski oluline, sest tähtsam on, kuidas verbi praegu kasutatakse.

Järelikult käib ÕS-i soovitus (norming), et verbi vabandama ei ole soovitatav kasutada tähenduses 'vabandust paluma', tänapäeval tugevasti vastu tegelikule keelekasutusele (objektiivsele keelenormile). Kasutuspõhist infot arvestavas EKI ühendsõnastikus 2020 (Sõnaveebis) ongi tähenduste järjekorda võrreldes ÕS-i ja varase- 
mate seletavate sõnaraamatutega muudetud: 1) 'vabandust paluma', 2) 'õigustama', 3) 'andeks andma, andestama' - varem esitati esimesena tähendus 'andeks andma, andestama'.

Keelekorraldusel peab tähendusmuutuste asjus olema oma seisukoht, nagu on öelnud Valter Tauli (1968: 110). Nii ütleski vabariikliku õigekeelsuskomisjoni liige Ülle Viks 1980. aastal, et sagedasti kasutatavate üldkeelesõnade tähendusi ja kasutamist ei saa ette kirjutada (Viks 1985: 72). Ometi normiti 160 [+9] sõna seas ÕS 1999-s ka verbi vabandama tähendust ja nii on see väljaandest väljaandesse jäänud; nõnda kanti see (esialgu) ka EKI ühendsõnastikku 2020. Verb vabandama kuulub eesti keele põhisõnavarasse (see esineb eesti keele põhisõnavara sõnastikus), olles seega sagedasti kasutatav sõna, mille tähendusi ja kasutust ei saa sõnaraamatus ette kirjutada.

Olnud alates 2020. aasta jaanuarist Eesti Keele Instituudis keelenõuandja, olen juba paar korda tundnud kimbatust, sest nõuandjana pean verbi vabandama ebasoovitatavale tähendusele tähelepanu juhtima, ehkki ise sellesse ei usu. Olen olukorra lahendanud, öeldes, et ÕS-is soovitatakse ühtmoodi, aga tegelikus keelekasutuses tarvitatakse verbi enamasti teistmoodi. Andmebaasist on näha, et keelenõusse on vabandama-teemal helistatud vähemalt alates 1993. aastast, aga küllap tehti seda varemgi. Vastus püsib sama: tähendus 'vabandust paluma' on venepärane ega ole soovitatav. Minu hinnangul on see ilmekas näide, et eesti keelekorralduses on vaja tugevamaid teoreetilisi aluseid, mis põhinevad põhjalikel keeleuuringutel, mitte ammustel keeleautoriteetide eelistustel-arvamustel. Oma seisukohtadele peavad seega õigustuse otsima mõlemad pooled: nii normingute kaitsjad kui ka õonestajad.

ÕS-i soovitus verbi vabandama kohta põhineb Henn Saari 1969. aasta eeldusel (vt Saari 1976: 84-85, 87), mis on nüüdseks pool sajandit vana. Saari võis olla mõjutatud ka oma aja hoiakust, mil venepärasust püüti tõrjuda (Raag 2008: 247; Tavast 2012: 232), tänapäevaste uurimisvõimaluste juures on aga selge, et verbi vabandama kasutust on juba mitu sajandit tagasi mõjutanud hoopis saksa keel. Kehayovi ja Vihmani (2014) uurimuse põhjal paistab, et saksa päritolu autorid, kes eesti keelt kirjeldasid ja tekste eesti keelde tõlkisid, tõid transitiivse entschuldigen'i ja enesekohase sich entschuldigen'i vasteteks kedagi/midagi vabandama ning end vabandama (kellegi ees). Aja jooksul kadusid kedagi/midagi ja end aina enam konstruktsioonidest, neid polnud enam vaja, sest sõnatähendus oli kontekstis selge (vt Cruse 1995: 16). Samuti on keelekasutusele omane ökonoomiataotlus: mida sagedasem on sõna (siin: konstruktsioon), seda lühemaks ta kulub (Bybee 2010: 20). Nõnda arenes verbile vabandama kolm tähendust, millest kaks on vastandlikud. Mõne polüseemse sõna tähendused võivadki sadu aastaid kõrvuti eksisteerida, ehkki nende kasutuse osakaal võib muutuda (Traugott, Dasher 2002: 12).

Pole harv, et sama sõna võidakse kasutada vastupidistes tähendustes, nt sõna palun, mis nii esitab palvet kui ka annab luba (vt Keevallik 2003: 140-152). Polüseemsus ei ole pahenähtus keeles, nagu on arvanud J. V. Veski (1967: 333), vaid keelele loomuomane ilming (Raiet 1976: 152; McMahon 1999: 176; Traugott, Dasher 2002: 12). Niisiis ei peaks Emakeele Seltsi keeletoimkonna tähenduste laiendamise otsused olema mitte „esmajoones vastutulek neile, kes senist normingut omandada 
pole suutnud või soovinud", nagu on öelnud Maire Raadik (2015: 209), vaid normimisel tulebki rohkem arvestada keelekasutust ja -uuringuid.

Kokkuvõttes, kasutades Valter Tauli (1968: 111) sõnu: „Kui tähendusmuutus on saand üldiseks, siis tuleb see aktsepteerida." Pole kahtlustki, et verbi vabandama kasutus tähenduses 'vabandust paluma' on saanud üldiseks ning ÕS-i norming on objektiivsest keelenormist liiga palju maha jäänud ja tuleb ära muuta.

Verbi vabandama tähenduste analüüsitulemused eri perioodidel koondab joonis 2. Ühendasin joonisel XIX sajandi kohta VAKK-i ja DIGAR-i korpuse andmed. Korpuste peale kokku analüüsisin 13248 lauset, vastavate perioodide lausete koguhulka tähistab joonisel $n$-täht.

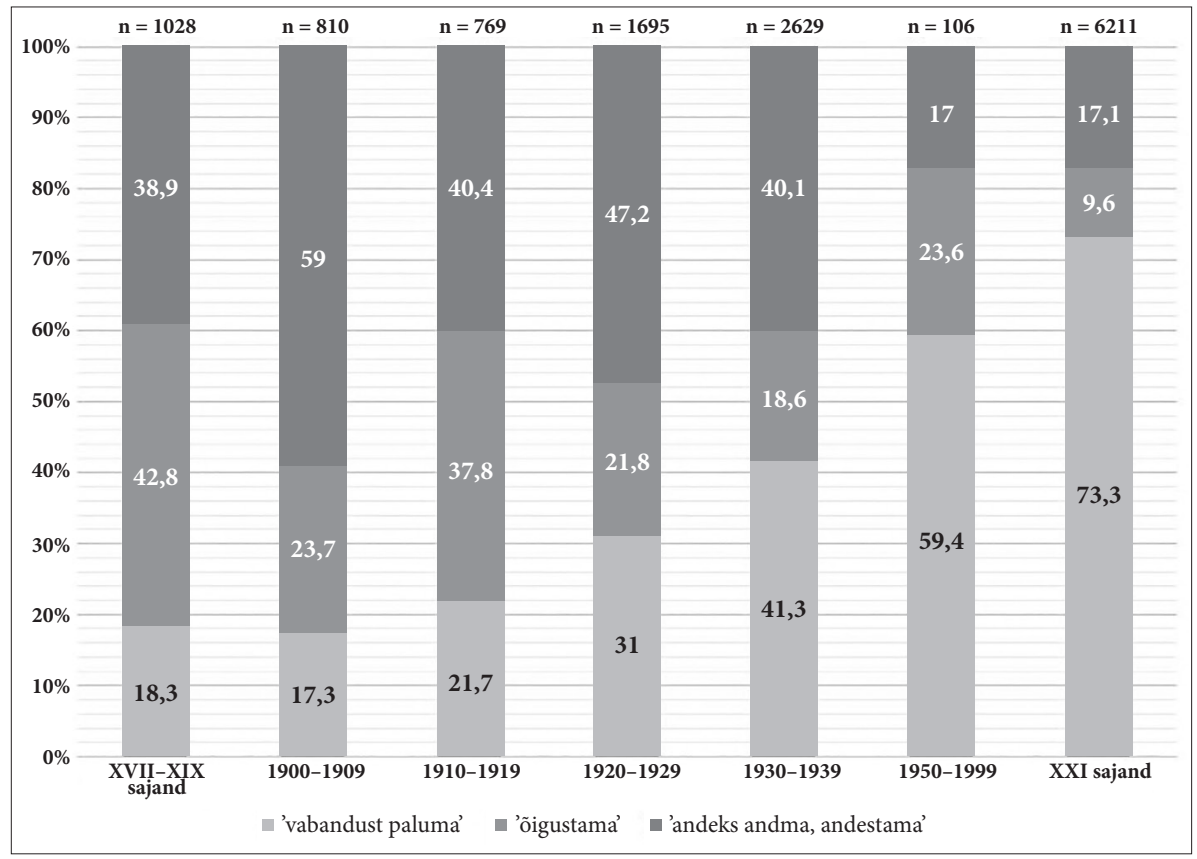

Joonis 2. Verbi vabandama tähenduste jagunemine XVII-XXI sajandil perioodide kaupa.

\section{Kokkuvõte}

Eesti keelekorralduses toetutakse paljuski traditsioonile, mitte ajakohastele keeleuuringutele, mida ei ole ka tehtud. 1980. aastal leidis vabariiklik õigekeelsuskomisjon, et sagedasti kasutatavate üldkeelesõnade tähendusi ei saa ette kirjutada, sest tähendused võivad keeles kiiresti muutuda, aga 1999. aasta õigekeelsussõnaraamatusse lisati ikkagi osale sõnadest tähenduspiiranguid ning tähenduste ebasoovitatavaks pidamine jätkub siiani. 1993. aastast tegutsev Emakeele Seltsi keeletoimkond on küll mõne sõna tähenduspiire laiendanud, ent käsitletud on ainult üksikuid sõnu. ÕS-i koostajad on samuti eri väljaannetes mõne sõna uusi tähendusi aktsepteerinud, teiste omi aga mitte. 
Üks piiratud tähendusega sõna on verb vabandama, mille tähendus 'vabandust paluma' on soovitatavate tähenduste 'õigustama' ja 'andeks andma, andestama' kõrval olnud pikka aega ebasoovitatav, sest Henn Saari pidas 1969. aastal seda vigaseks tõlkeks vene keelest. Tänapäeval on võimalik korpuste põhjal uurida tegelikku (korrigeerimata) keelekasutust, mida peetakse kasutuspõhises teoorias peamiseks uurimisobjektiks. Artiklis kirjeldasin verbi vabandama eri tähendustes esinemist, mis väljendas selgesti, et tähenduses 'vabandust paluma' kasutati verbi märgatavalt juba XIX sajandi viimasel veerandil, seda saksa keele enesekohaselt kasutatud verbi sich entschuldigen eeskujul enamasti konstruktsioonis end vabandama (kellegi ees). XX sajandi jooksul selline kasutus süvenes, lisaks jäeti aina enam verbi juurest ära enesekohane asesõna end, kuni 1990. aastateks kasutati verbi vabandama tähenduses 'vabandust paluma' juba valdavalt. Tänapäeval kasutatakse seda verbi seega enamasti tema ebasoovitatavas tähenduses.

Nii on verbi vabandama näitel selge, et ÕS-i tähendussoovitused (normingud) vajavad tegeliku keelekasutuse andmete (objektiivse keelenormi) ja uurimistöö põhjal ajakohastamist. Siinne artikkel on loodetavasti samm selle poole.

Artikli kirjutamist on toetanud teadusprojekt EKKD64 „Eesti keele sõnavara ja korraldus: deskriptiivne ja preskriptiivne vaatenurk".

\section{VEEBIVARAD}

DIGAR-i Eesti artiklid. Eesti Rahvusraamatukogu digitaalarhiiv. http://data.digar.ee

EKI ühendsõnastik 2020. Eesti Keele Instituudi keeleportaal Sõnaveeb. https://sonaveeb.ee ETÜ = Eesti etümoloogiasõnaraamat. Koost ja toim Iris Metsmägi, Meeli Sedrik, Sven-Erik Soosaar. Peatoim I. Metsmägi. https://www.eki.ee/dict/ety

Kallas, Jelena; Koppel, Kristina 2018. Eesti keele ühendkorpus 2017. (Estonian National Corpus 2017.) Eesti Keeleressursside Keskus. https://doi.org/10.15155/3-00-0000-00000000-071e71

Kallas, Jelena; Koppel, Kristina 2020. Eesti keele ühendkorpus 2019. (Estonian National Corpus 2019.) Eesti Keeleressursside Keskus. https://doi.org/10.15155/3-00-0000-00000000-08565L

Sketch Engine. https://www.sketchengine.eu

Tinits, Peeter 2020. Eesti Rahvusraamatukogu digilabori tööriistad tekstimaterjali ligipääsuks ja töötlemiseks. Zenodo. http://doi.org/10.5281/zenodo.3953795

TÜKK = Eesti kirjakeele korpus 1890-1990. https://cl.ut.ee/korpused/baaskorpus

VAKK = Prillop, Külli 2013. Vana kirjakeele korpus. Eesti Keeleressursside Keskus. https://doi. org/10.15155/1-00-0000-0000-0000-00075L

\section{KIRJANDUS}

Barlow, Michael; Kemmer, Suzanne 2000. Usage Based Models of Language. Stanford, California: CSLI Publications.

Burridge, Kate; Bergs, Alexander 2017. Understanding Language Change. London-New York: Routledge. 
Bybee, Joan 2010. Language, Usage and Cognition. Cambridge: Cambridge University Press.

Croft, William 2000. Explaining Language Change. An Evolutionary Approach. Harlow etc.: Longman.

Cruse, David Alan 1995. Lexical Semantics. Cambridge: Cambridge University Press.

EKK = Mati Erelt, Tiiu Erelt, Kristiina Ross 2020. Eesti keele käsiraamat. Uuendatud väljaanne. Tallinn: Eesti Keele Instituut, EKSA.

EKÕS 1918 = Eesti keele õigekirjutuse-sõnaraamat. Eesti Kirjanduse Seltsi väljaanne. Tallinn: K.-Ü. „Rahvaülikooli” kirjastus.

Elisto, Elmar 1948. Keelelisi küsimusi I. Tallinn: RK Pedagoogiline Kirjandus.

Erelt, Tiiu 1976. Keel normiliistul. - Keel, mida me harime. Koost Mart Mäger. Tallinn: Valgus, lk 20-23.

Erelt, Tiiu 2000. Mida tahab keelekorraldus. - Oma Keel, nr 1, lk 23-26.

Erelt, Tiiu 2002. Eesti keelekorraldus. Tallinn: Eesti Keele Sihtasutus.

Erelt, Tiiu 2007a. Terminiõpetus. Toim Maire Raadik. Tartu: Tartu Ülikooli Kirjastus.

Erelt, Tiiu 2007b. Õigekeelsussõnaraamatud läbi sajandi. - ÕS-i lätted. Koost Urmas Sutrop. Tallinn: Eesti Keele Sihtasutus, lk 5-34.

Habicht, Külli; Keevallik, Leelo; Tragel, Ilona 2006. Keele muutumine kasutuskontekstis. Keel ja Kirjandus, nr 8, lk 609-625.

Habicht, Külli; Penjam, Pille; Prillop, Külli 2015. Heinrich Stahli tekstide sõnastik. Tartu: Tartu Ülikooli Kirjastus.

Hennoste, Tiit 1996. Tartu University Corpus of Written Estonian: a survey of the structure of texts and principles of selection. - Estonian in the Changing World. Toim Haldur Õim. Tartu: University of Tartu, lk 7-32.

Hennoste, Tiit 2017. Suhtluskiilud. - Eesti keele süntaks. (Eesti keele varamu III.) Toim Mati Erelt, Helle Metslang. Tartu: Tartu Ülikooli Kirjastus, lk 494-496.

Hint, Mati 1976. Kahemõtteline keel. - Keel, mida me harime. Koost Mart Mäger. Tallinn: Valgus, lk 141-146.

Hurtta, Heikki 2006. Kielenhuolto kunniaan. - Kielikello, nr 1, lk 28-29.

Isad 1990 = Isad. Talmudi 4. osa 9. traktaat. Tlk Andres Gross, Marju Lepajõe. Tallinn: Perioodika.

Kaplan, Robert B.; Baldauf, Richard B. jr 1997. Language Planning From Practice to Theory. Clevedon, UK: Multilingual Matters.

Kasik, Reet 2011. Stahli mantlipärijad. Tartu: Tartu Ülikooli Kirjastus.

Kasik, Reet 2015. Sõnamoodustus. (Eesti keele varamu I.) Tartu: Tartu Ülikooli Kirjastus.

Keevallik, Leelo 2003. From Interaction to Grammar. Estonian Finite Verb Forms in Conversation. (Studia Uralica Upsaliensia 34.) Uppsala: Acta Universitatis Upsaliensis.

Kehayov, Petar; Vihman, Virve 2014. The lure of lability: A synchronic and diachronic investigation of the labile pattern in Estonian. - Linguistics, kd 52, nr 4, lk 1061-1105.

Kerge, Krista 2012. Keelekorralduse põhimõtted. - Sirp 27. IX.

Kilgarriff, Adam; Rychlý, Pavel; Smrž, Pavel; Tugwell, David 2004. The Sketch Engine. Proceedings of the $11^{\text {th }}$ EURALEX International Congress. Toim Geoffrey Williams, Sandra Vessier. Lorient: Université de Bretagne Sud, lk 105-115.

Kindlam, Ester 1976. Meie igapäevane keel. Tallinn: Valgus. 
Kingisepp, Valve-Liivi; Prillop, Külli; Habicht, Külli 2004. Eesti vana kirjakeele korpus: mis tehtud, mis teoksil. - Keel ja Kirjandus, nr 4, lk 272-280.

Koks, Helen 2002. Kuidas aega väljendavast sidesõnast kuna sai põhjuslik. - Oma Keel, nr 2, lk 42-48.

Koppel, Annika 2018. Saja-aastane ÕS täieneb pidevalt. - Maaleht 22. XI.

Koppel, Kristina; Tavast, Arvi; Langemets, Margit; Kallas, Jelena 2019. Aggregating dictionaries into the language portal Sõnaveeb: issues with and without a solution. - Proceedings of the eLex 2019 conference. 1-3 October 2019, Sintra, Portugal. Toim Iztok Kosem, Tanara Zingano Kuhn, Margarita Correia, José Pedro Ferreria, Maarten Jansen, Isabel Pereira, J. Kallas, Miloš Jakubíček, Simon Krek, Carole Tiberius. Brno: Lexical Computing CZ, s.r.o, lk 434-452.

Kull, Rein 1969. Quo vadit eesti õigekeelsussõnaraamat. Mis oli, mis on ja mida me teame. Keel ja Kirjandus, nr 11, lk 641-652.

Kull, Rein 1976. Kas normisund või piiramatu vabadus. - Keel, mida me harime. Koost Mart Mäger. Tallinn: Valgus, lk 24-28.

Langacker, Ronald 1987. Foundations of Cognitive Grammar: Theoretical Prerequisites. Stanford: Stanford University Press.

Langemets, Margit 2009. Nimisõna süstemaatiline polüseemia eesti keeles ja selle esitus eesti keelevaras. (Humanitaarteaduste dissertatsioonid 10.) Tallinn: Tallinna Ülikooli Kirjastus.

Langemets, Margit; Tiits, Mai; Uibo, Udo; Valdre, Tiia; Voll, Piret 2018. Eesti keel uues kuues. - Keel ja Kirjandus, nr 12, lk 942-958.

Leinonen, Jaana 2005. Huono kieli ärsyttää. Opiskelijoiden ja toimistotyöntekijöiden käsityksiä kielenhuollosta. Magistritöö. Oulun yliopisto.

Liivaku, Uno 1978. Kust king keelt pigistab. Tallinn: Valgus.

Luther, Martin 2000 [1530]. Kiri tõlkimisest ja pühakute eestpalvest. Tlk Kristiina Ross. Vikerkaar, nr 2-3, lk 83-96.

McMahon, April M. S. 1999. Understanding Language Change. Cambridge: Cambridge University Press.

Muuk, Elmar 1940. Väike õigekeelsus-sõnaraamat. 7. trükk. Tartu: Eesti Kirjanduse Selts.

Päll, Peeter 2005. Võõrnimed eestikeelses tekstis. (Dissertationes philologiae Estonicae Universitatis Tartuensis 15.) Tartu: Tartu Ülikooli Kirjastus.

Päll, Peeter 2019. Kirjaviis. - Eesti õigekeelsuskäsiraamat. https://keeleabi.eki.ee/viki/Kirjaviis.html (8. VI 2020).

Raadik, Maire 1993. Kas vabandame või vabandage? - Hommikuleht 23. IV.

Raadik, Maire 2015. Mida uut on õigekeelsussõnaraamatus? - Keelenõuanne soovitab 5. Toim M. Raadik, Tiiu Erelt. Tallinn: Eesti Keele Sihtasutus, lk 203-212.

Raadik, Maire 2019. Emakeele Seltsi keeletoimkonna veerandsajand. - Oma Keel, nr 1, lk 54-67.

Raag, Raimo 2008. Talurahva keelest riigikeeleks. Tartu: Atlex.

Raiet, Erich 1976. Mõnda eesti kirjakeele sõnaraamatust. - Keel, mida me uurime. Koost Mart Mäger. Tallinn: Valgus, lk 150-153.

Ross, Kristiina; Piits, Liisi 2019. Mõlgutusi tõest eesti keelekirjelduses. - Keel ja Kirjandus, nr 8-9, lk 686-694. 
Rätsep, Huno 1976a. Murdekeel ja kirjakeel. - Keel, mida me harime. Koost Mart Mäger. Tallinn: Valgus, lk 121-124.

Rätsep, Huno 1976b. Lindu tuntakse laulust, inimest keelest. - Keel, mida me harime. Koost Mart Mäger. Tallinn: Valgus, lk 116-120.

Saareste, Andrus 1952. Kaunis emakeel. Lund: Eesti Kirjanike Kooperatiiv.

Saari, Henn 1976. Keelehääling. Tallinn: Valgus.

Saari, Henn 2004. Keelehääling: Eesti Raadio „Keeleminutid” 1975-1999. Tallinn: Eesti Keele Sihtasutus.

Tauli, Valter 1968. Keelekorralduse alused. Uppsala: Kirjastus Vaba Eesti.

Tauli, Valter 1974. The theory of language planning. - Advances in Language Planning. Toim Joshua A. Fishman. The Hague-Paris: De Gruyter Mouton, lk 49-67.

Tavast, Arvi 2012. Keelehoolde teoreetilise aluse otsinguil: naabervaldkonnad appi. - Sõnaga mõeldud mõte. Koost, toim Maire Raadik, Tiina Leemets. Tallinn: Eesti Keele Sihtasutus, lk 224-235.

Tavast, Arvi; Langemets, Margit; Kallas, Jelena; Koppel, Kristina 2018. Unified data modelling for presenting lexical data: The case of EKILEX. - Proceedings of the XVIII EURALEX International Congress. EURALEX: Lexicography in Global Contexts, Ljubljana, 17-21 July. Toim Jaka Čibej, Vojko Gorjanc, Iztok Kosem, Simon Krek. Ljubljana: Ljubljana University Press, Faculty of Arts, lk 749-761.

Traugott, Elizabeth Closs; Dasher, Richard B. 2002. Regularity in Semantic Change. Cambridge-New York: Cambridge University Press.

Uuspõld, Ellen 1976. Põhimõtteline keelekorraldus. - Keel, mida me harime. Koost Mart Mäger. Tallinn: Valgus, lk 5-8.

Veski, Johannes Voldemar 1967. Keele sõnavara vaesestumise vastu. - Keel ja Kirjandus, $\mathrm{nr} 6$, lk 333-337.

Viks, Ülle 1985. Sõnaseiku. - Kirjakeele teataja 1979-1983. Koost Tiiu Erelt, Henn Saari. Tallinn: Valgus, lk 66-72.

Õim, Haldur 1976. Semantikast. - Keel, mida me harime. Koost Mart Mäger. Tallinn: Valgus, lk 125-129.

ÕS 1976 = Õigekeelsussõnaraamat. Toim Rein Kull, Erich Raiet. Koost Tiiu Erelt, R. Kull, Valve Põlma, Kristjan Torop. ENSV TA Keele ja Kirjanduse Instituut. Tallinn: Valgus.

ÕS 1999 = Eesti keele sõnaraamat ÕS 1999. Toim Tiiu Erelt. Koost T. Erelt, Tiina Leemets, Sirje Mäearu, Maire Raadik. Tallinn: Eesti Keele Sihtasutus.

ÕS 2006 = Eesti õigekeelsussõnaraamat ÕS 2006. Toim Maire Raadik. Koost Tiiu Erelt, Tiina Leemets, Sirje Mäearu, M. Raadik. Eesti Keele Instituut. Tallinn: Eesti Keele Sihtasutus.

ÕS 2013 = Eesti õigekeelsussõnaraamat ÕS 2013. Toim Maire Raadik. Koost Tiiu Erelt, Tiina Leemets, Sirje Mäearu, M. Raadik. Eesti Keele Instituut. Tallinn: Eesti Keele Sihtasutus.

ÕS 2018 = Eesti õigekeelsussõnaraamat ÕS 2018. Toim Maire Raadik. Koost Tiiu Erelt, Tiina Leemets, Sirje Mäearu, M. Raadik. Eesti Keele Instituut. Tallinn: EKSA.

Lydia Raadik (snd 1988), MA, Eesti Keele Instituudi nooremteadur (Roosikrantsi 6, 10119 Tallinn), lydia.raadik@eki.ee 


\title{
Standardisation of meanings in Estonian corpus planning on the example of the verb vabandama
}

\author{
Keywords: Estonian corpus planning, word meanings, language change
}

Estonian corpus planning relies noticeably on traditions, not on up-to-date language research, which there is none. For example, in 1980 the Orthological Committee decided that the meanings of the words should not be standardized since they change rapidly, but the Dictionary of Standard Estonian (ÕS) published in 1999 still had some restrictions in the definitions and some of the meanings still continue to be inadvisable. The Language Committee of the Estonian Mother Tongue Society, active since 1993, expanded the meanings of some words, but merely a few words have been inspected.

One of the words with a limited meaning is the verb vabandama with the suggested meanings 'justify' and 'forgive.' The definition 'apologise' has been inadvisable for a long time only because in 1969 linguist Henn Saari classified this meaning as an incorrect translation from the Russian language. Nowadays it is possible to use text corpora for the studies of the actual (unrevised) use of language, which is considered to be the main subject of the usage-based theory. In this article I introduce the analytical results of the usage of the verb vabandama in different meanings. The results clearly demonstrate that the verb was widely used in the meaning of 'apologise' already in the second half of the $19^{\text {th }}$ century. Following the example of the German verb sich entschuldigen, the reflexive form end vabandama was used. During the $20^{\text {th }}$ century this usage intensified. In addition, the verb vabandama was increasingly used without a reflexive pronoun end. In the 1990s the verb vabandama was already used predominantly in the meaning of 'apologise'. Now, in the $21^{\text {st }}$ century, this verb is mostly used in its inadvisable sense. It is thus clear from the example of the verb vabandama that the suggested meanings (standardisations) in the Dictionary of Standard Estonian need an upgrade based on actual language usage (objective language standards) and research.

Lydia Raadik (b. 1988), MA, Institute of the Estonian Language, Junior Researcher (Roosikrantsi 6, 10119 Tallinn), lydia.raadik@eki.ee 